\title{
Comparative Study of Two Different Structures of Collagen Scaffold for Bone Formation
}

\author{
Andrea Paola Rodriguez ${ }^{1}$, Hitoshi Nagatsuka ${ }^{1}$, Bingzhen Huang ${ }^{1,2}$, Kan Rui ${ }^{1,2}$, Mika Okauchi ${ }^{1}$, \\ Yoshie Kagawa ${ }^{3}$, Missana Liliana ${ }^{4}$, Shinichiro Oida ${ }^{5}$, Noriyuki Nagai ${ }^{1}$ \\ ${ }^{1}$ Okayama University, Graduate School of Medicine, Dentistry and Pharmaceutical Sciences \\ ${ }^{2}$ Dental Titanium Giken, Okayama \\ ${ }^{3}$ Japan Institute for Advanced Dentistry, Osaka \\ 4Tucuman University, Argentina \\ ${ }^{5}$ Tsurumi University, Dental School
}

\begin{abstract}
It has not been determined the best scaffold-structure for bone engineering. Because of this, we compared Honeycomb porous structure (HPS) and Interconnected porous structure (IPS) with or without KUSA/ A1 cells implanted in mice. The transplants were subjected to radiological and histological examinations after $1,2,4$ and 8 weeks of implantation.

KUSA/A1 cells alone showed small islands of new bone. Both scaffolds alone did not reveal any bone induction. KUSA/A1-HPS presented the scaffold partially filled with new bone. In contrast, KUSA/A1-IPS showed the whole scaffold filled with new bone. Our results indicated that cotton structure plays an important role in carrying the cells giving the precise size, shape and comfortable environment.

Keywords: Honeycomb porous structure, Interconnected porous structure, KUSA/A1 cells
\end{abstract}

\section{Introduction}

The basic principle of tissue engineering is to use seeded cells in a appropriate scaffold to generate a certain type of tissue either in vivo or in vitro. Recently, implantation of cell on scaffold has taken a great importance in bone engineering. Until now, it has not been reported a comparative study of different structure of atelocollagen scaffold to induce bone formation. Thus in this study, we compared interconnected porous structure (Fig.1) and honeycomb porous structure ${ }^{1}$ (Fig.2) combined with KUSA/A1 ${ }^{2}$ cell line implanted in subcutaneous tissue of SCID mouse.

\section{Materials and Methods}

In this study, 4-week-old male Severe Combined Immunodeficient (SCID) mice, KUSA-A1 (kindly provided by Dr. Umezawa, Center of Human Development), HPS: honeycomb porous structure (Koken, Japan) and IPS: interconnected porous structure (Koken, Japan) were used. 0.0035 gram of each scaffold combined with $1 \times 10^{6} \mathrm{KUSA} / \mathrm{A} 1$ cells; $5 \times 10^{6}$ of KUSA/A1 cells alone, HPS and IPS alone were implanted in the subcutaneous tissues. The transplants were subjected to radiological and histological examinations after 1,2,4 and 8 weeks of implantation.

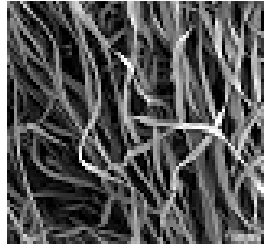

Fig.1 SEM of IPS

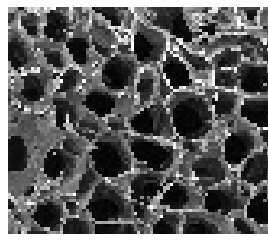

Fig. 2 SEM of HPS

\section{Results and Conclusion}

The histological findings are described in table 1. Both scaffolds alone did not reveal any bone induction. KUSA/A1-IPS showed the whole scaffold filled with new bone (Fig.3). In contrast, KUSA/ A1-HPS presented the scaffold partially filled with new bone (Fig.4). Our results indicated that cotton structure plays an important role in carrying the cells giving the precise size, shape

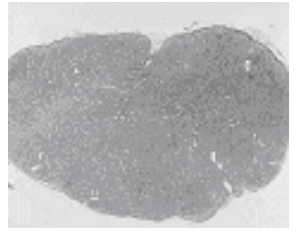

Fig.3 The whole IPS was filled of mature bone at 8 weeks

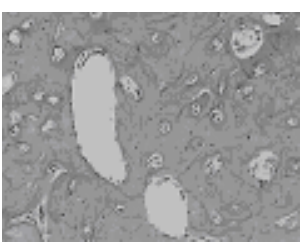

Fig.4 No evidence of bone formation in the center and comfortable environment.

In conclusion, this scaffold combined with autologous stem cells could become a primary resource in future therapeutic strategy.

\section{References}

1) Hiroshi I, Yu A, Masayasu F, Yasuharu $N$ and Teruo M. Artif Organs, 25 (3): 213-221;2001

2) Umezawa A, Maruyama T, Segawa K, Shadduck RK, Waheed A and Hata J. J Cell Physiol, 151(1): 197-205;1992 
J.Hard Tissue Biology.14(2)Proceeding,2005

\begin{tabular}{|c|c|c|c|c|}
\hline Groups / Period & 1 week & 2 weeks & 4 weeks & 8 weeks \\
\hline HPS alone & Inflammatory reaction & Inflammatory reaction & High inflammatory reaction & High inflammatory reaction \\
\hline IPS alone & $\begin{array}{l}\text { No inflammatory reaction. } \\
\text { Presence of spindle cells }\end{array}$ & $\begin{array}{l}\text { Spindle cells proliferation } \\
\text { and vessel formation }\end{array}$ & $\begin{array}{l}\text { No inflammation. Presence } \\
\text { of connective tissue }\end{array}$ & $\begin{array}{l}\text { No inflammation. Presence } \\
\text { of connective tissue }\end{array}$ \\
\hline $\begin{array}{l}\text { KUSA/A1 } \\
\text { alone }\end{array}$ & $\begin{array}{l}\text { Small nest of immature } \\
\text { bone surrounded by } \\
\text { KUSA/A1 cells }\end{array}$ & $\begin{array}{l}\text { Small nest of immature } \\
\text { bone surrounded by } \\
\text { KUSA/A1 cells }\end{array}$ & $\begin{array}{l}\text { Small nest of immature } \\
\text { bone surrounded by } \\
\text { KUSA/A1 cells }\end{array}$ & $\begin{array}{l}\text { Small nest of lamellar-like } \\
\text { bone surrounded by } \\
\text { KUSA/A1 cells }\end{array}$ \\
\hline $\begin{array}{r}\text { KUSA/A1-HPS } \\
\mathrm{K} \\
\mathrm{f}\end{array}$ & $\begin{array}{l}\text { Inflammatory reaction and } \\
\text { KUSA/A1 cell proliferation } \\
\text { from the periphery }\end{array}$ & $\begin{array}{l}\text { Inflammatory reaction } \\
\text { and KUSA/A1 cell } \\
\text { proliferation from } \\
\text { the periphery }\end{array}$ & $\begin{array}{l}\text { Central core of few cells and } \\
\text { vessels surrounded by newly } \\
\text { bone }\end{array}$ & $\begin{array}{l}\text { No evidence of bone formation } \\
\text { in the center of the scaffold }\end{array}$ \\
\hline KUSA/A1-IPS I & High cellular proliferation & $\begin{array}{l}\text { The whole IPS was filled } \\
\text { of new bone and cell } \\
\text { proliferation }\end{array}$ & $\begin{array}{l}\text { The whole IPS was filled } \\
\text { of new bone }\end{array}$ & $\begin{array}{l}\text { The whole IPS was filled } \\
\text { of mature bone }\end{array}$ \\
\hline
\end{tabular}

